\title{
Biological effects of anti-CD34-coated ePTFE vascular grafts. Early in vivo experimental results
}

\author{
Wojciech Mrówczyński ${ }^{1}$, Alessio Rungatscher ${ }^{2}$, Franz Buchegger ${ }^{3}$, Jean-Christophe Tille ${ }^{4}$, Sophie Namy ${ }^{3}$, \\ Osman Ratib ${ }^{3}$, Michael Kutryk ${ }^{5}$, Beat Hans Walpoth ${ }^{6}$ \\ ${ }^{1}$ Department of Pediatric Cardiac Surgery, Poznan University of Medical Sciences, Poznan, Poland \\ ${ }^{2}$ Department of Cardio-Vascular Surgery, University of Verona, Faculty of Medicine, Verona, Italy \\ ${ }^{3}$ Department of Radiology/Nuclear Medicine, University Hospitals of Geneva, Faculty of Medicine, Geneva, Switzerland \\ ${ }^{4}$ Department of Pathology, University Hospitals of Geneva, Faculty of Medicine, Geneva, Switzerland \\ ${ }^{5}$ Division of Cardiology, St. Michael's Hospital, Toronto, Canada \\ ${ }^{6}$ Department of Cardio-Vascular Surgery, University Hospitals of Geneva, Faculty of Medicine, Geneva, Switzerland
}

Kardiochirurgia i Torakochirurgia Polska 2014; 11 (2): 182-190

\begin{abstract}
Aim of the study: To assess the biological activity of anti-CD34 antibody-coated ePTFE vascular prostheses.

Material and methods: Indium ${ }^{111}$-labeled autologous thrombocytes were administered to 5 anesthetized pigs after the placement of femoral arterial and venous catheters. An arterio-venous fistula, created by the random interposition of 4 different ePTFE grafts $(A=$ dry control, $B=$ dry anti-CD34, $C=$ wet control, $D=$ wet anti-CD34), was blood perfused for $0,10,30,60$ and 120 minutes. Radioactivity of each graft was measured and expressed in cpm/mg. Morphological studies were performed to assess intraluminal deposition.

Results: The median radioactivity of graft $B$ was significantly higher than that of graft A after 60 min (1074 vs. 18; $p=0.021)$ and 120 min (1990 vs. 25; $p=0.043$ ) of perfusion. Similarly, graft D was significantly more active than graft C (60 min: 1388 vs. $26 ; p=0.021$ and 120 min: 2780 vs. $23 ; p=0.021)$. Histological and SEM results confirmed the radio-labeling in-vivo studies by showing significantly more protein/cell and platelet depositions ( $p=0.012$ ).

Conclusions: Anti-CD34-coated ePTFE grafts bound significantly more platelets/cells and proteins than their uncoated counterparts, confirming the bioactivity of the antibody. This process is time-dependent and matches the morphological results. The anti-CD34 coating may enhance temporal and spatial endothelialization of vascular grafts and, thus, possibly improve clinical results by providing direct endothelial progenitor cell (EPC) adhesion/entrapment or by creating a biocompatible protein-thrombocyte/cell layer that indirectly enhances migration and further proliferation of EPCS.

Key words: coated ePTFE, anti-CD34, vascular grafts, arteriovenous fistula, thrombus, platelets.
\end{abstract}

\section{Streszczenie}

Cel pracy: Ocena aktywności biologicznej protez naczyniowych z ePTFE (expanded polytetrafluoroethylene) powlekanych przeciwciałami anty-CD34.

Materiat i metody: Autologiczne płytki krwi znakowane indem ${ }^{111}$ podano pięciu znieczulonym świniom po wprowadzeniu żylnych i tętniczych cewników do naczyń udowych. Przez przetokę tętniczo-żylną, utworzoną poprzez losową kombinację 4 różnych protez naczyniowych z ePTFE ( $A$ = sucha kontrola, $\mathrm{B}=$ sucha $\mathrm{z}$ anty-CD34, $\mathrm{C}=$ mokra kontrola, $D=$ mokra $z$ anty-CD34), przepuszczano krew w cyklach trwających $0,10,30,60$ oraz 120 minut. Radioaktywność każdego z wszczepów została zmierzona i wyrażona w cpm/ mg. Wykonano badania morfologiczne, aby ocenić stan wewnętrzej ściany protez.

Wyniki: Średnia radioaktywność wszczepu B była znacząco wyższa od wszczepu A po 60 min (1074 vs 18; $p=0,021)$ oraz 120 min (1990 vs 25; $p=0,043)$ perfuzji. Również proteza D wykazywała znacząco wyższą aktywność niż implant C (60 min: 1388 vs 26; $p=0,021$ oraz 120 min: 2780 vs 23; $p=0,021)$. Wyniki badań histologicznych oraz badań z użyciem SEM (scanning electron microscopy) potwierdzity wyniki radioznakowania przeprowadzonego in vivo, wykazując obecność znacząco większych ilości złogów białkowych/komórkowych i płytkowych $(p=0,012)$.

Wnioski: Protezy naczyniowe z ePTFE pokrywane przeciwciałem anty-CD34 wiązały znacząco więcej płytek/komórek oraz białek niż protezy natywne, co potwierdza bioaktywność przeciwciała. Proces ten jest zależny od czasu i odpowiada wynikom morfologicznym. Powłoka anty-CD34 może wzmacniać czasowo i przestrzennie proces endotelializacji wszczepów naczyniowych oraz, być może, poprawiać wyniki kliniczne po-

Address for correspondence: Wojciech Mrówczyński, MD, PhD, Department of Pediatric Cardiac Surgery, Poznan University of Medical Sciences, Szpitalna 27/33, 60-572 Poznań, Poland, tel. +48 61849 12 77, e-mail: wjmrow@ump.edu.pl 
przez zapewnienie bezpośredniego mechanizmu wyłapywania i adhezji komórek EPC (endothelial progenitor cells) lub przez utworzenie biokompatybilnej warstwy białek-trombocytów/ komórek pośrednio zwiększającej migrację i dalszą proliferację komórek EPC.

Słowa kluczowe: ePTFE, wszczepy naczyniowe, przetoka tętniczo-żylna, trombocyty.

\section{Introduction}

The use of expanded polytetrafluoroethylene (ePTFE) based materials is commonplace in contemporary medicine, especially for cardiovascular applications where there is a demand for biocompatible artificial vascular grafts. Although ePTFE vascular grafts provide excellent mechanical and handling properties, post-implant endothelialization is poor. This feature is crucial for small diameter grafts, particularly long grafts, in which the midportion of the prosthesis is rarely covered by native endothelial cells (ECS) [1]. Small diameter grafts that lack a healthy endothelial coverage are at risk of thrombotic occlusion, and, therefore, continuous anticoagulation is required. Intimal hyperplasia is the second major drawback of ePTFE prostheses that can potentially jeopardize their long-term patency. This phenomenon is again attributed to the absence of normal confluent endothelium and its microenvironmental influences that are responsible for the control of smooth muscle cell proliferation and migration.

Bone marrow-derived endothelial progenitor cells (EPCS) are a subset of circulating endothelial cells responsible for vascular and myocardial repair processes after injury and ischemia [2, 3]. These cells express the vascular endothelial growth factor receptor VEGFR-2, as well as the CD133 and CD34 antigens [3], and they possess great proliferative capacity. EPCs can form a functional endothelial lining on different polymers and have a positive influence on neointimal formation [4]. Thus, EPCs seem to be a promising means for neoendothelialization in tissue engineering and in the biofunctionalization of artificial vascular grafts including ePTFE prostheses.

As growing EPC tissue cultures can be time- and resource-consuming, a strategy was developed that relies on attracting and entrapping the circulating EPCS on the internal surface of the vascular graft. This is theoretically accomplished by an anti-CD34 antibody coating. This strategy has been proven to be feasible in experimental studies [5] as well as in the clinical application of anti-CD34-coated coronary artery stents [6-8]. The anti-CD34 coating can potentially accelerate uniform endothelialization, contributing to improving the patency of small caliber vascular grafts.

The aim of this study was to assess the biological activity of anti-CD34 antibody-coated ePTFE vascular prostheses and to verify the hypothesis of CD34 cell adhesion. The second aim was to verify whether different storage environments (aqueous or dehydrated) of the coated grafts influence their biological activity.

\section{Material and methods \\ Animal preparation}

The experimental protocol was approved by the Animal Experiments Ethics Committee of the University of Geneva and the Veterinary Office of the State of Geneva (Switzerland; No. 10813271/3) and carried out in conformance with the Guide for the Care and Use of Laboratory Animals (National Research Council, Washington, D.C.: National Academy Press; 1996).

Five male Swiss Landrace pigs (mean weight: $41.3 \mathrm{~kg}$, range: $39-45 \mathrm{~kg}$ ) were premedicated with $3 \mathrm{mg} / \mathrm{kg}$ azaperone (Stresnil - Roche, Switzerland), anesthetized with 2\% isoflurane (Isoflurane - Abbott, Switzerland), $4 \mathrm{mg}$ pancuronium bromide (Pavulon - Organon, Switzerland), and $0.5 \mathrm{mcg} / \mathrm{kg} / \mathrm{min}$ fentanyl (Fentanyl - Sintetica, Switzerland), and intubated. The animals were ventilated with a Servo Ventilator 900D respirator (Siemens, Germany) as well as monitored by the use of 3-lead ECG, $\mathrm{SpO}_{2}$, and direct arterial blood pressure measurement (AS/3 cardiomonitor - Datex, Finland). The animals were heparinized (10 $000 \mathrm{IU})$ in order to obtain an ACT value of $2 \mathrm{X}$ baseline (Hemochrone, Datex). Additional heparin was administered in $200 \mathrm{IU}$ increments if the target ACT was not achieved. After bilateral groin incisions, the femoral veins and arteries were identified, and $8 \mathrm{~F}$ catheters were inserted using the Seldinger method. $37.5 \mathrm{~mL}$ of blood was withdrawn in $2.5 \mathrm{~mL}$ EDTA in order to harvest autologous thrombocytes that were consecutively labeled with indium ${ }^{111}\left({ }^{111} \mathrm{In}\right)$ and re-administered to animals. An arterio-venous (A-V) fistula was constructed and perfused according to the protocol described below. At the end of this acute experiment, all animals were sacrificed by potassium chloride overdose.

\section{Preparation of autologous platelets}

Porcine platelets were purified from whole blood containing citrate phosphate dextrose (CPD) solution (7 mL CPD/ $40 \mathrm{~mL}$ blood) by differential centrifugation initially at $200 \mathrm{xg}$ for 15 minutes. The pellet containing sedimented white blood cells (WBC) and erythrocytes was discarded and CPD $(10 \% \mathrm{v} / \mathrm{v})$ was added to the platelet-containing supernatant and then centrifuged at $1000 \times \mathrm{g}$ for $10 \mathrm{~min}$ to yield sedimented platelets. Platelets were then labeled with ${ }^{111}$ In-Oxine (DRN 4908, Mallinckrodt Medical B.V., Le Petten, Netherlands) as previously described [9]. Sedimented platelets were briefly re-suspended in $3.0 \mathrm{~mL} \mathrm{NaCl}(0.15 \mathrm{M})$ and $0.4 \mathrm{~mL}$ Tris buffer (Mallinckrodt Medical) and $1 \mathrm{~mL}{ }^{111}$ In-Oxine solution and incubated for $20 \mathrm{~min}$ at $22^{\circ} \mathrm{C}$. Platelet-poor plasma 
(PPP) was added in the amount of $0.6 \mathrm{~mL}$, and the mixture was centrifuged at $1000 \times \mathrm{g}$ for $15 \mathrm{~min}$, yielding radiolabelled platelets. Sedimented platelets, ready for use, were reconstituted in $3 \mathrm{~mL}$ of PPP. The activity of the sample was measured using a gamma-counter (Cobra II, Perkin-Elmer, MA, USA).

\section{Anti-CD34-coated graft preparation}

An ultrathin dextran coating was applied to the luminal surface of the commercially available ePTFE graft material (Bard Peripheral Vascular Inc., USA) using plasma technology. The surface was then functionalized, and CD34 antibody was covalently bound to the surface. The prepared grafts were then placed in saline solution containing $0.1 \%$ azide (wet grafts) or were lyophilized and exposed to $25 \mathrm{kGy} \gamma$ radiation for sterilization (dry grafts). These two groups were included in order to assess the influence of storage conditions (lyophilized vs. aqueous solution) on the biological activity of the antibody.

\section{The AV fistula}

The ipsilateral femoral arterial and venous catheters were connected with one another by the random interposition of the vascular grafts to be assessed (diameter: $4 \mathrm{~mm}$, length: $25 \mathrm{~mm}$ ) - non-coated: A - dry ePTFE and C - wet ePTFE (Bard Peripheral Vascular Inc., USA), and coated: B dry anti-CD34-coated ePTFE and D - wet anti-CD34-coated ePTFE (Orbus Neich, USA) joined by metallic connectors.

All the grafts were secured using ligatures encircling the prostheses around the connector. The dry grafts were connected to the circuit without pre-wetting. The wet grafts were rinsed generously with $0.9 \%$ saline before use. Blood pressure (AS/3 cardio-monitor - Datex, Finland) and flow through the fistula (MediStim, Oslo, Norway) were continuously monitored. The thrombocyte count of the pig as well as whole blood radioactivity were determined before and after each run of the circuit. The fistulas were perfused for $0,10,30,60$, and 120 minutes (bilateral fistulas were used: one for the $120 \mathrm{~min}$ cycle and a second one for the other cycles in order to minimize the time of the experimental procedure). Thus, each of the 4 graft types was perfused in 5 animals $(n=5)$ for 5 different periods. Consecutive runs of the fistula were performed in the following order: $120,10,30$, and $60 \mathrm{~min}$. After each fistula run, the grafts were removed, and both the arterial and venous arms were flushed with heparinized saline.

\section{Specimen processing}

After the end of each fistula cycle, all the vascular grafts were cut and rinsed with $50 \mathrm{~mL}$ of saline at $100 \mathrm{~cm} \mathrm{H}_{2} \mathrm{O}$ pressure. The radioactivity of each sample was then measured by gamma counting (Cobra II, Perkin-Elmer, MA, USA) 1 and 2 hours after the experiment, showing minimal decay, as expected ( $p=n s)$. The first measurements were used for statistical analysis. All specimens were weighed, and radioactivity was expressed in counts per minute per milligram of the prosthesis for the purpose of normalization. After this assessment, all samples were fixed in 4\% formaldehyde for 24 hours and then divided into two parts: for histology and scanning electron microscopy (SEM) studies.

\section{Histology}

For histological analysis, all 120 min perfusion samples were embedded in paraffin. Transverse histological sections $(4 \mu \mathrm{m})$ were stained with hematoxylin and eosin (H\&E). The reason for performing histological and immunohistological studies on the grafts perfused for 120 min was twofold: as this was the first run of the fistula, it could potentially best reflect the early prosthesis-blood interaction without being biased by previous perfusions. Secondly, the first and longest perfusion time should maximize the likelihood of EPC entrapment on the lumen of the graft.

In order to characterize the cells adhering to the graft lumen, immunostaining was performed as follows: paraffin sections $(4 \mu \mathrm{m})$ were deplasticized in warm xylene and ethanol, which was followed by their incubation in a graded series of alcohols and deionized water. Antigen retrieval was performed using heat, with the sections placed in Tris-EDTA buffer ( $\mathrm{pH}$ 9.0). The slides were then placed in $3 \% \mathrm{H}_{2} \mathrm{O}_{2}$ for 20 minutes, which was followed by blocking in horse serum and immunostaining using the following monoclonal anti-human antibodies: CD34 (dilution 1: 25; Lifespan Biosciences, USA), CD62E/62P (dilution $1: 10$, Geneway, USA), CD31 (dilution $1: 25, A b D$ SerotecUK), and CD133 (dilution 1 : 100; AbCam, USA) diluted in PBS ( $\mathrm{pH} 7.5$ ) at $4^{\circ} \mathrm{C}$ overnight. For the reaction with the secondary antibody and increased sensitivity, we used a Vectastain Elite $A B C$ kit (Vector Labs Inc). Positive staining was visualized by a 3,3'diaminobenzidine (DAB) chromogen. The sections were counterstained with hematoxylin.

Pictures were taken at 100x and 200x magnification, using a Nikon Eclipse TS 100 microscope with a DS-Fi1 camera and a DS-L2 digital camera controller (Nikon, Japan) attached.

The slides were also analyzed quantitatively by computed histomorphometry with a motorized microscope (Nikon Eclipse 1, Japan) at 10x magnification and with image-processing software (ImageJ, US National Institutes of Health, 2010). The internal graft lumen area as well as intraluminal deposit area were measured.

\section{Scanning electron microscopy}

For SEM study, all samples were prepared with standard dehydration and gold coating techniques. A scanning electron microscope (Philips XL series, Netherlands) was utilized applying magnifications ranging from x100 to x1000. A semiquantitative specimen analysis was performed, taking into account the presence of separate cells, cell conglomerates, intraluminal deposits, and microthrombi.

\section{Statistical analysis}

The variables were expressed as medians and ranges. The normality of variable distribution was assessed by the 
Tab. I. Mean platelet counts during the experiment

\begin{tabular}{lcccccc} 
Variable & Unit & Baseline & After $120 \mathrm{~min}$ & After $10 \mathrm{~min}$ & After $30 \mathrm{~min}$ & After $60 \mathrm{~min}$ \\
PLT count & $\times 10^{3} / \mathrm{mm}^{3}$ & $366 \pm 18$ & $329 \pm 83$ & $316 \pm 146$ & $298 \pm 111$ & $259 \pm 116$ \\
\hline Throm &
\end{tabular}

Thrombocyte count before the first and after each consecutive run of the arterio-venous fistula.

PLT - platelets

Shapiro-Wilk test. The inter-group comparisons were performed using the Mann-Whitney U-test (A vs. B, C vs. D, A+ C vs. $B+D)$. A nonparametric Friedman ANOVA test was used for the intra-group repeated comparisons. Nonparametric Spearman correlations were performed to assess the relationship between sample activity and time. The investigators were not blinded to the nature of the different experimental grafts as storage methods were different.

A two-tailed $p$ value of less than 0.05 was considered significant in all tests.

\section{Results}

\section{AV fistula}

The animals' platelet (PLT) counts measured before and after the AV shunt runs were diminishing, but the change was not significantly different - Table I. Whole blood activity changed insignificantly after each fistula run. The activity of each graft type during various perfusion times is presented in Figure 1. There was a significant difference between grafts $A$ and $B$ after 60 and 120 min of perfusion. The activities of grafts $C$ and $D$ were significantly different after 30, 60, and 120 min of AV fistula perfusion run duration. There were no significant differences between grafts $B$ and $D$ or between grafts $A$ and $C$ after all the AV fistula perfusion periods.

The activities of grafts $B$ and $D$ changed significantly over time $(p=0.003$ and $p=0.012)$, while the values for grafts $A$ and $C$ remained constant $(p=0.061$ and $p=0.072$ ). The activities of grafts $B$ and $D$ correlated strongly with time of perfusion (respectively: $r=0.93$ at $p=0.003$ and $r=0.87$ at $p=0.0001$ ), whereas the results of grafts $A$ and D showed only a weak relationship $(r=0.46$ at $p=0.05$ and $r=0.47$ at $p=0.04$ ).

\section{Histology and planimetry}

The results of the histological analyses are presented in Figure 2. After 120 min of perfusion, grafts $A$ and $C$ were characterized mainly by the presence of cells (granulocytes) adhering randomly to the inner surface of the graft. Acellular deposits (proteins, fibrin, and platelets) were not present or were extremely rare and occupied only a small part of the internal perimeter of the graft (not shown). Grafts $B$ and $D$ exhibited the presence of a thick layer of acellular deposits (proteins, fibrin, and platelets) accompanied by the presence of cells (granulocytes).

Immunostaining revealed no CD31+, CD62E/62P+, CD34+, or CD133+ cells in any grafts after 120 min of perfusion - Figure 3.

The median graft lumen area was similar $(p=N S)$ in non-coated $(A+C)$ and coated $(B+D)$ grafts, amounting to, respectively, $17.8 \mathrm{~mm}^{2}$ (16.4-18.8) and $17.9 \mathrm{~mm}^{2}$ (17.2-18.1), which demonstrated that the antibody coating did not significantly influence the inner diameter of the graft. There was a significant difference in the areas of intraluminal deposits between the coated and non-coated grafts - Figure 4 .

\section{Scanning electron microscopy}

All non-perfused grafts (0 $\mathrm{min}$ ) had a similar ePTFE structure, showing no visible difference between coated and non-coated grafts. After 10 minutes of blood perfusion, single cells were present on the surface of coated grafts only. Thirty and 60 minutes of perfusion resulted in the presence of single cells on grafts $A$ and $C$, while both coated grafts $(B+D)$ were covered with acellular deposits accompanied by single and conglomerate cells, platelets, as well as microthrombi. Similar results were observed after 120 min in coated grafts, whereas graft A showed only the presence of single and conglomerate cells. Some acellular deposits were found on the internal lumen of graft C - Table II, Figure 5.

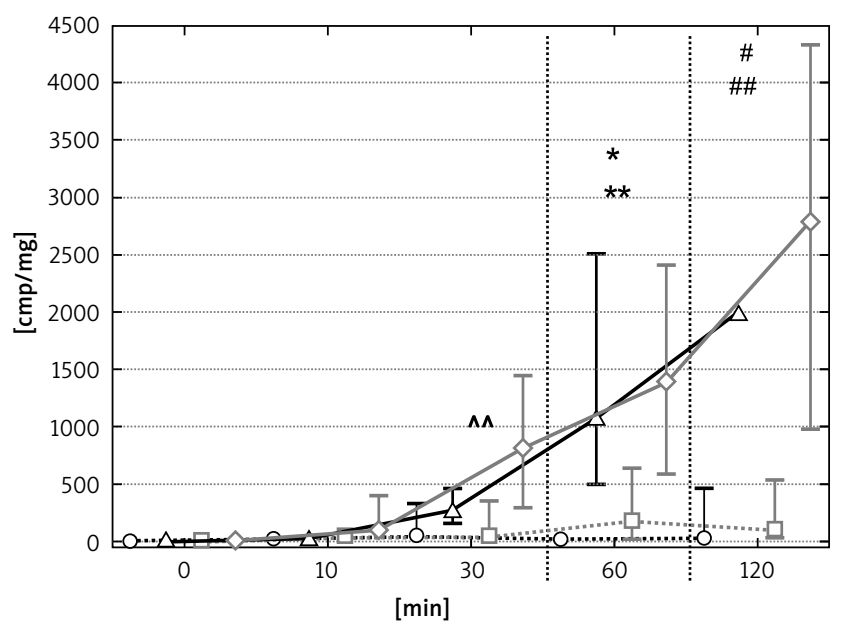

$$
\begin{aligned}
& \text { …․ㅗ A - Dry control - 조 B - Dry anti-CD34 }
\end{aligned}
$$

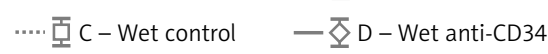

$$
\begin{aligned}
& { }^{*} A \text { vs. } B \text { at } 60 \mathrm{~min}, p=0.021 \\
& \# A \text { vs. } B \text { at } 120 \mathrm{~min}, p=0.043 \\
& \wedge \wedge \text { C vs. D at } 30 \mathrm{~min}, p=0.043 \\
& { }^{\star *} C \text { vs. } D \text { at } 60 \mathrm{~min}, p=0.021 \\
& \text { \#\# C vs. D at } 120 \mathrm{~min}, p=0.021
\end{aligned}
$$

Fig. 1. Radioactivity according to perfusion time and graft type. A) Dry control ePTFE vascular graft. B) Dry anti-CD34-coated ePTFE vascular graft. C) Wet control ePTFE vascular graft. D) Wet antiCD34-coated ePTFE vascular graft. Note the significantly higher radioactivity (indium ${ }^{111}$-labelled platelets) of coated prostheses ( $B$ and $D$ ) in comparison to uncoated grafts ( $A$ and $C$ ) after 30 min (only graft C vs. D), 60 min, and 120 min of AV shunt blood perfusion 


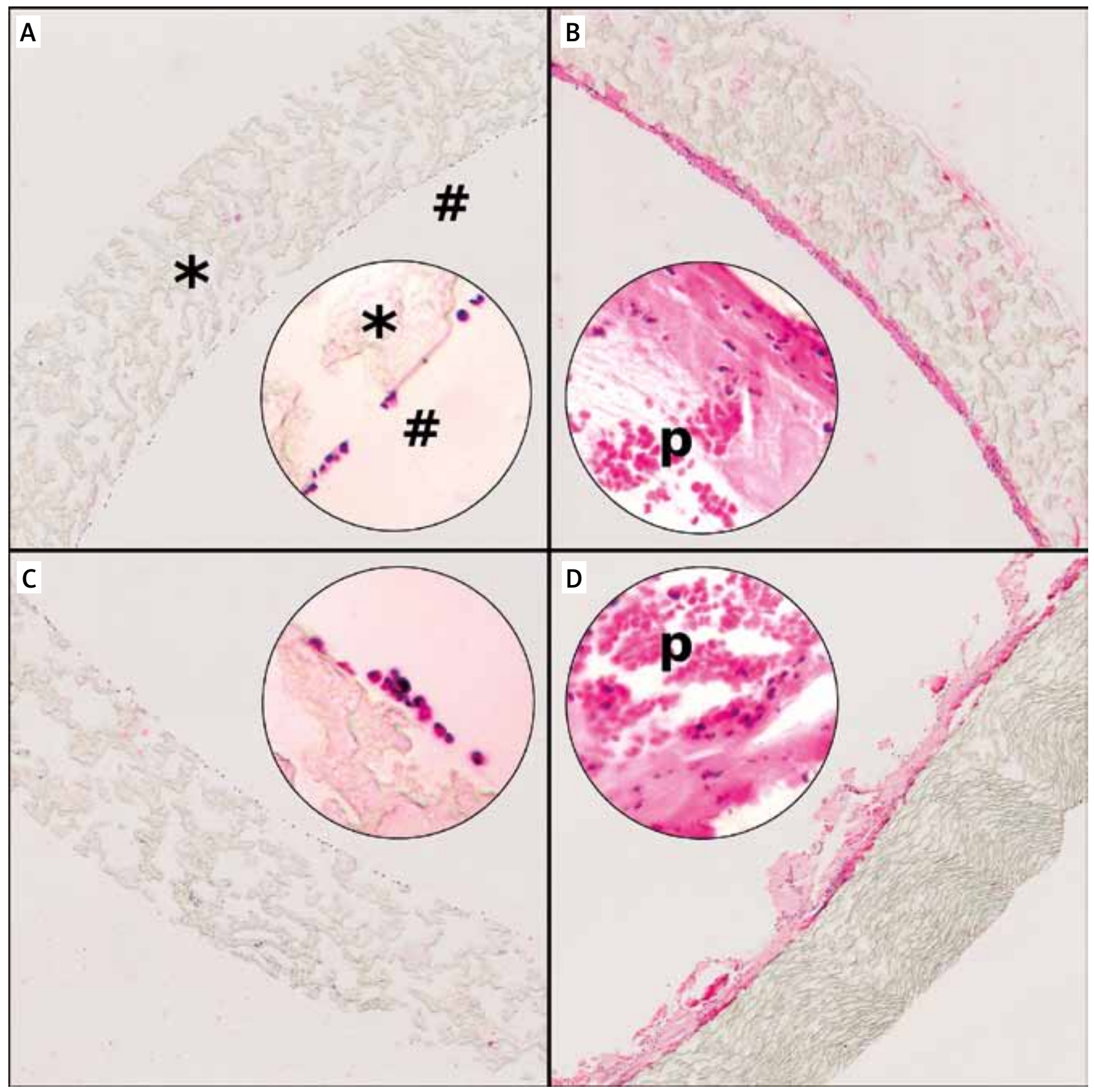

*Cross-section of the ePTFE prosthesis, \# Luminal surface of the ePTFE prosthesis, $p$ - Porcine thrombocytes

Fig. 2. Microscopic picture of blood-perfused vascular grafts after $120 \mathrm{~min}$ of perfusion (magnification 10x and 400x - insets). A) Dry control ePTFE vascular graft. B) Dry anti-CD34-coated ePTFE vascular graft. C) Wet control ePTFE vascular graft. D) Wet anti-CD34-coated ePTFE vascular graft. Note the presence of thick intraluminal coverage composed of proteins, platelets, and nucleated cells in coated grafts ( $B$ and $D)$, whereas non-coated prostheses show only minimal adherence of cells

\section{Discussion}

This study shows that anti-CD34-coated ePTFE vascular grafts are able to bind significantly more porcine platelets and proteins than their non-coated equivalents. Both dry and wet coated grafts showed similar binding capacity, indicating no influence of different storage environments on the biological activity of the bound antibody. This is of fundamental importance with respect to the ease of preparation and longevity of storage in the case of dried/lyophi- lized implants. The process of lyophilization can change the conformation of the active epitopes of proteins, which may result in inactivation of the antibody [10]. The deposition of porcine platelets was assessed indirectly by measurement of the radioactivities of indium ${ }^{111}$-labelled PLTs adhering to the inner surface of the studied grafts. The presence of antigen CD34 on the surface of both human and porcine platelets has been described [11, 12]. The results of histological, planimetric, and SEM studies were in concordance 


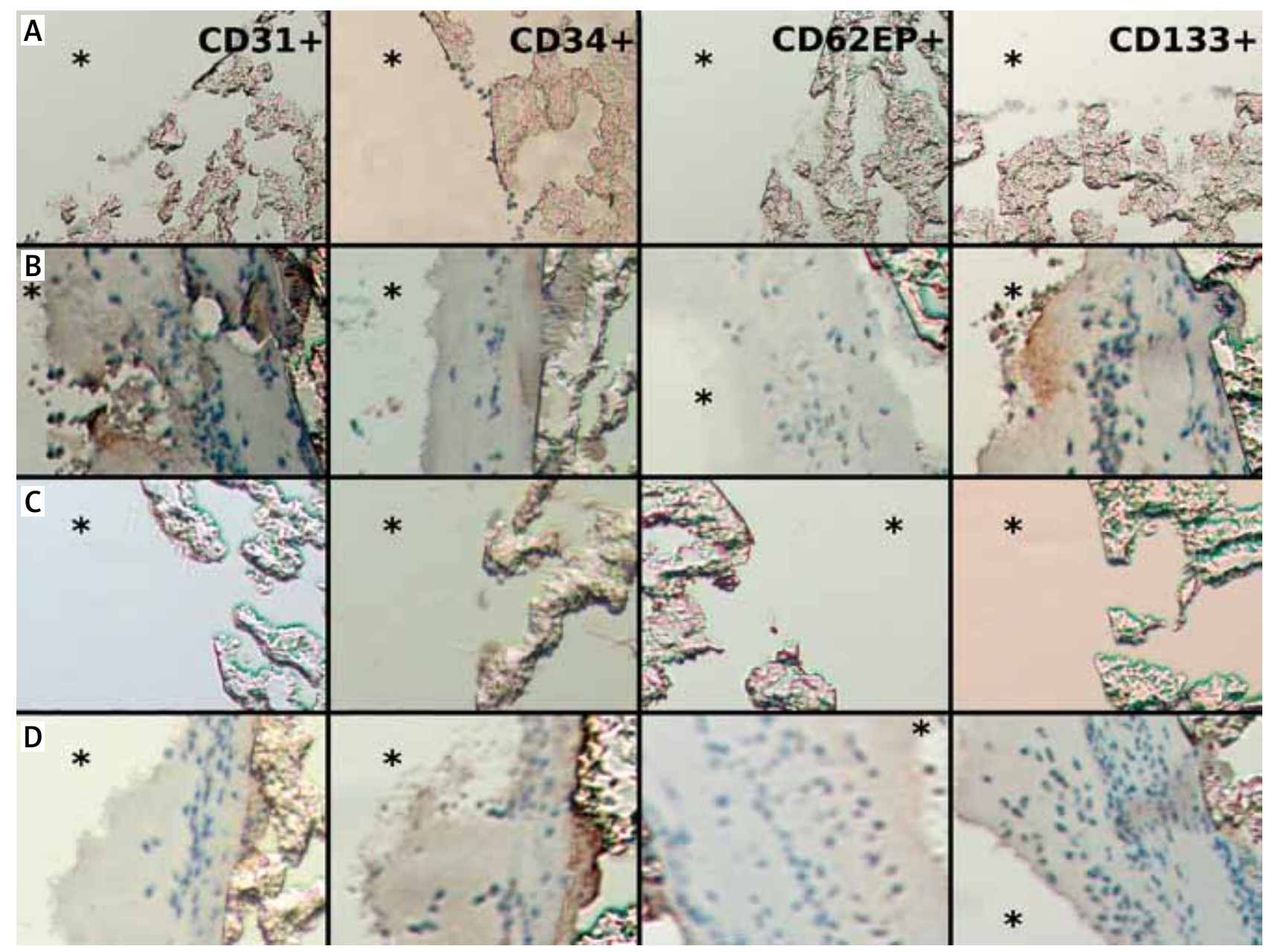

* - Luminal surface of the ePTFE prosthesis

Fig. 3. Results of immunostaining with anti-CD31, anti-CD34, anti-CD62EP, and anti-CD133 antibodies (magnification 200x). All grafts after 120 min of perfusion. No positive staining for EPC visible in any grafts or any antibody type. A) Dry control ePTFE vascular graft. B) Dry anti-CD34-coated ePTFE vascular graft. C) Wet control ePTFE vascular graft. D) Wet anti-CD34-coated ePTFE vascular graft

with the quantitative radio-labeling assays. The non-coated grafts showed a significantly smaller area of intraluminal coverage in comparison to the anti-CD34-coated prostheses after $120 \mathrm{~min}$ of perfusion. The deposits on coated grafts consisted of platelets, fibrin, and nucleated cells (mainly neutrophils), which was also visible on SEM analysis. To our knowledge, this is the first report that describes the early phase of interaction between blood and an antiCD34-coated vascular graft in an experimental setting.

The phenomenon described above can certainly raise some questions concerning the clinical applicability of a prosthesis that attracts PLTs and has the potential to induce thrombosis. However, this problem does not seem to be important in humans since no acute patency problems were reported with the use of anti-CD34-coated coronary artery stents [6-8]. Of course, the intensity of thrombocyte and fibrin deposition can also be attributed to the higher density of the anti-CD34 antibody, its higher absolute count, and finally its uniform spatial localization on the internal lu-

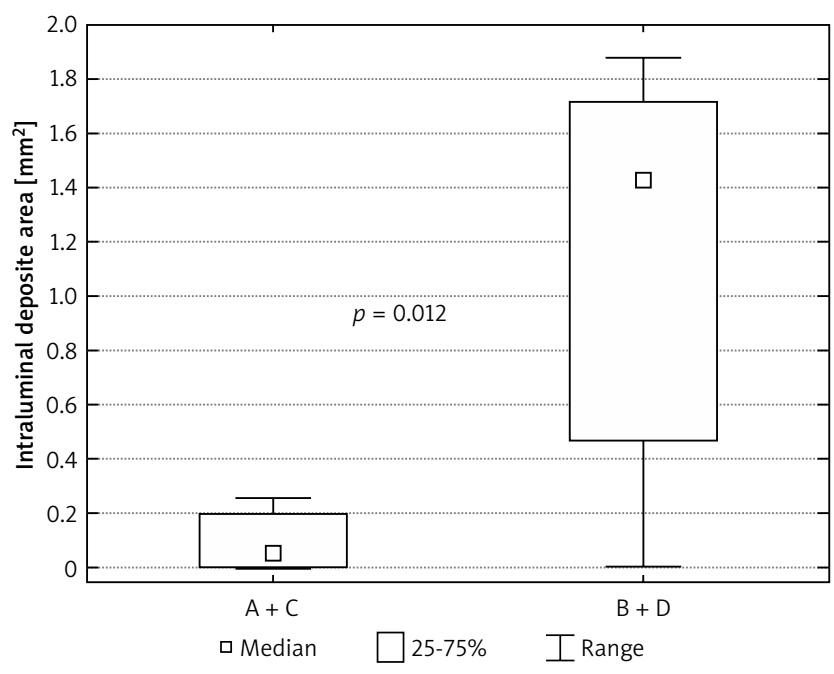

Fig. 4. Intraluminal coverage area after 120 min of perfusion histological planimetry study. A + C) Dry and wet control ePTFE vascular graft (uncoated). B + D) Dry and wet anti-CD34-coated ePTFE vascular graft 
Tab. II. Semiquantitative analysis of scanning electron microscopy images of luminal surfaces of non-perfused $(0 \mathrm{~min})$ and perfused (10-120 min) grafts

\begin{tabular}{|c|c|c|c|c|c|c|}
\hline $\begin{array}{l}\text { Graft } \\
\text { type }\end{array}$ & Characteristics & $\begin{array}{c}0 \\
\min \end{array}$ & $\begin{array}{c}10 \\
\mathrm{~min}\end{array}$ & $\begin{array}{c}30 \\
\min \end{array}$ & $\begin{array}{c}60 \\
\mathrm{~min}\end{array}$ & $\begin{array}{l}120 \\
\mathrm{~min}\end{array}$ \\
\hline \multirow{4}{*}{ A } & Single cells & & & + & + & + \\
\hline & Conglomerate cells & & & & & + \\
\hline & Acellular deposit & & & & & \\
\hline & Microthrombi & & & & & \\
\hline \multirow{4}{*}{ B } & Single cells & & + & + & + & + \\
\hline & Conglomerate cells & & & + & + & + \\
\hline & Acellular deposit & & & + & + & + \\
\hline & Microthrombi & & & + & + & + \\
\hline \multirow{4}{*}{ C } & Single cells & & & + & + & + \\
\hline & Conglomerate cells & & & & & + \\
\hline & Acellular deposit & & & & & + \\
\hline & Microthrombi & & & & & \\
\hline \multirow{4}{*}{$\mathrm{D}$} & Single cells & & + & + & + & + \\
\hline & Conglomerate cells & & & + & + & + \\
\hline & Acellular deposit & & & + & + & + \\
\hline & Microthrombi & & & + & + & + \\
\hline
\end{tabular}

$A$-dry control ePTFE vascular graft, $B$ - dry anti-CD34-coated ePTFE vascular graft, $C$ - wet control ePTFE vascular graft, D - wet anti-CD34-coated ePTFE vascular graft

men of the ePTFE prosthesis in comparison to the minimal surface of anti-CD34-coated coronary artery stents.

Fibrin and platelet deposition may not necessarily be detrimental since animal experiments with anti-CD34coated grafts, including this study, did not reveal frequent thrombotic events. In a chronic AV shunt pig model, Rotmans et al. found good patency of anti-CD34 antibodycoated grafts up to 28 days [5]. This may be related to the fact that CD34 is expressed on non-activated thrombocytes only [11]. Moreover, the experimental studies on mixed coating of adhesive polypeptide and anti-CD34 showed diminished aggregation of thrombocytes on such modified layers [13]. Platelet and fibrin depositions can also be advantageous as the prosthesis is immediately covered with the host's own materials, mainly proteins, rendering it more biocompatible in comparison to a bare graft [14].

A second possible disadvantage of platelet and fibrin deposition is the blockade of prosthesis activity. As PLTs are more numerous in the circulation than EPCs, the active anti-CD34 antibodies may become saturated before the arrival of CD34-positive endothelial progenitor cells. However, this can also be favorable as initial platelet adhesion seems to be an essential step for the recruitment of progenitor cells to areas of vascular injury [14]. Therefore, the thrombocytes may act indirectly with fibrin deposits as mediators attracting EPCs to the surface of injured vessels or the coated ePTFE vascular graft material [14]. PLTs increase the migration and differentiation of ECs into mature cells and promote the colonization of EPCs [15].

It has already been questioned whether the CD34 antigen is the best marker for EPCs that could further differentiate into a functional EC layer. Thus, different strategies for EPC entrapment were developed including the use of the antibody against VEGFR-2, which seems to be a better indicator of endothelial potential [16]. In order to enhance the action of anti-CD34, which is a potential initiator of adhesion to the prosthetic wall, an adhesive polypeptide of mussel origin combined with the anti-CD34 antibody was used [13]. Other approaches have employed integrins with integrin-binding cyclic Arg-Gly-Asp peptides (cRDG), magnetic molecules, or single-stranded nucleic acids - aptamers [17]. This last method appears to be very promising due to the high affinity of aptamers to their target cells and the ease of their production, entirely by synthetic means. However, insufficiently characterized EPC markers as well as the heterogeneity of EPC populations make their adhesion very difficult.

Despite our use of four different antibodies during immunostaining studies, we were not able to detect the presence of cells possessing the characteristics of EPCs. There are several possible reasons for this failure. All specimens were formalin-fixed and paraffin-embedded, which could have had an impact on epitope structure. Moreover, the application of anti-human antibodies in a porcine model could have resulted in a false negative outcome despite in-vitro tests showing a cross-reactivity of about $60-70 \%$ between human antibodies and pig cells (personal communication of M. Kutryk). In fact, no signal from deposited thrombocytes could be detected either. In addition, due to a very small number of circulating EPCs, these cells may not have been visualized in our immunostaining studies because of the relatively large active surface of the AV shunt. Finally, a controversial explanation of EPCs' absence in our immunostaining studies could be postulated in connection with the debate whether EPCs really exist and have a real role in biology $[18,19]$.

\section{Study limitations}

The cross-reaction between platelets and EPCs with the anti-CD34 antibody is certainly a limitation of this study as the CD34 antigens present on thrombocytes may rapidly saturate all the antibody active sites on the coverage of the prosthesis, preventing effective entrapment of relatively rare EPCS.

The in-vivo acute arterio-venous fistula setting is another potential limitation of the study as only an early phase (up to 2 hours) of prosthesis-host interaction is observed. The conditions of flow occurring in the extracorporeal AV shunt are not entirely physiological, which may influence the interaction between the prosthesis and blood as well as possibly activate leucocytes and thrombocytes. Similarly, the successive runs of the fistula circuit in the same animal could have certainly biased the results as the platelet and 


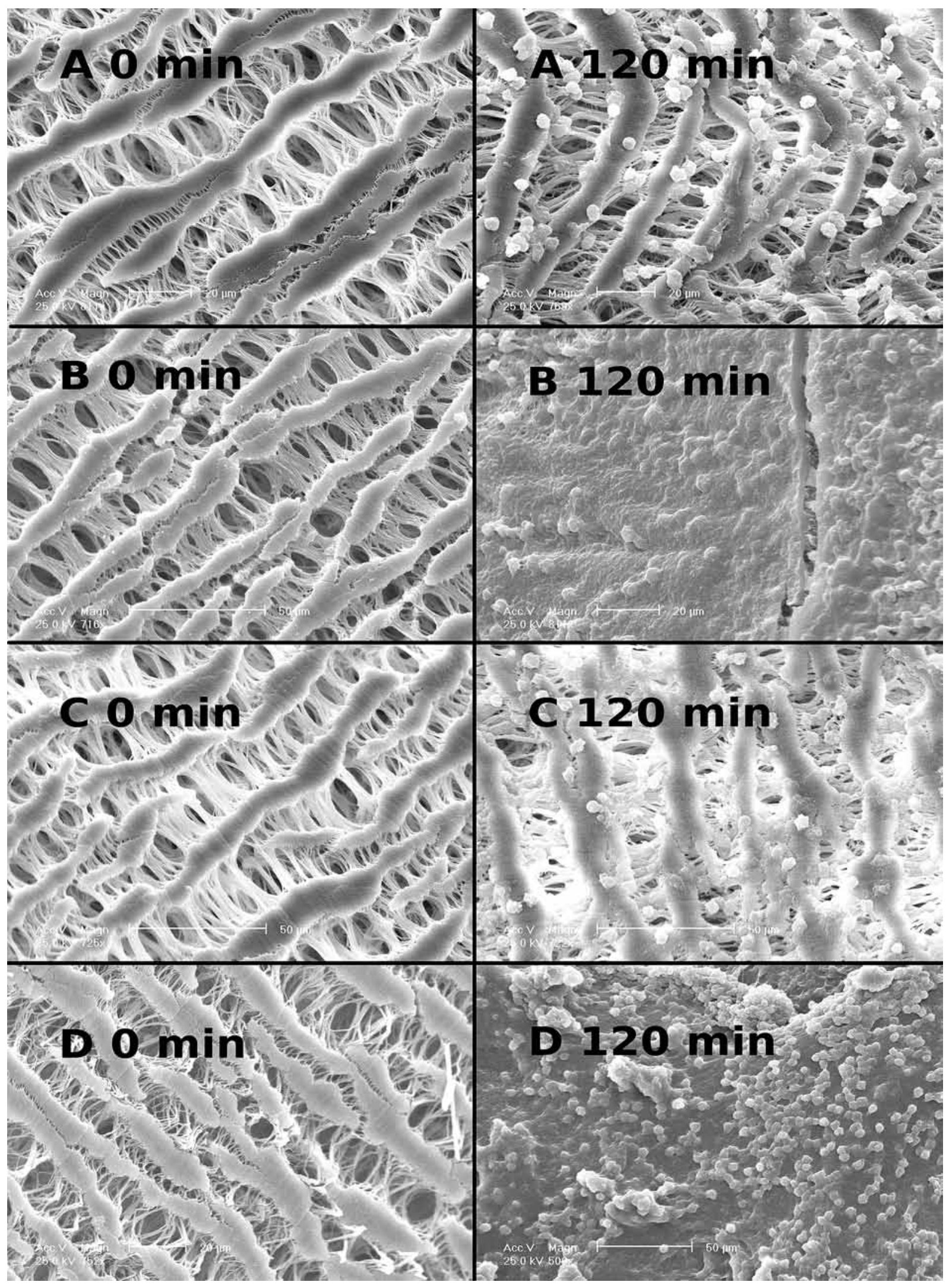

Fig. 5. SEM pictures of vascular grafts after 0 (not perfused) and 120 min of perfusion. A) Dry control ePTFE vascular graft. B) Dry anti-CD34-coated ePTFE vascular graft. C) Wet control ePTFE vascular graft. D) Wet anti-CD34-coated ePTFE vascular graft. Note the full coverage with protein platelets and cells of the luminal surface of the ePTFE graft in the antibody-coated prostheses B and D 
neutrophil activation could have occurred in the preceding sequence of the experiment.

A longer-term study with surgical implantation of the coated graft would likely provide better insight into the phenomenon of CD34-positive cell entrapment.

Finally, another important question is whether this model of early phase platelet-prosthesis interaction can be extrapolated to humans despite the fact that porcine thrombocytes react similarly to human PLTs in the presence of various biomaterials [20].

\section{Conclusions}

The anti-CD34-AB-coated grafts bind significantly more porcine proteins and platelets than uncoated prostheses in a time-dependent manner. The bioactivity of the antibody has been confirmed in complementary morphological studies and is not influenced by different graft storage environments. The coverage of the ePTFE graft by biological deposition may promote EPC adherence and differentiation into an endothelial cell layer. Thus, the anti-CD34 coating may enhance, directly or indirectly, the temporal and spatial endothelialization of vascular grafts and, thus, possibly improve clinical results. However, long-term animal studies are needed before its potential application in humans in order to confirm our hypothesis and study results of antiCD34-coated vascular graft implantation.

\section{Acknowledgements}

We acknowledge Mrs. Lutzen and Mrs. Reymond for their help in histological and scanning electron microscope processing as well as Mrs. Ivana Kandic for performing the immunohistochemical staining. We would also like to express our gratitude to Mrs. Melodie Kaeser for her help in the correction of this manuscript.

\section{Sources of funding/grants}

Swiss National Science Foundation Grant \#3100-56728. Samples provided free of charge by Orbus Neich.

\section{Disclosures}

Samples provided free of charge by Orbus Neich.

\section{References}

1. Zilla P, Bezuidenhout D, Human P. Prosthetic vascular grafts: wrong models, wrong questions and no healing. Biomaterials 2007; 28: 5009-5027.

2. Hill JM, Zalos G, Halcox JPJ, Schenke WH, Waclawiw MA, Quyyumi AA, Finkel T. Circulating endothelial progenitor cells, vascular function, and cardiovascular risk. N Engl J Med 2003; 348: 593-600.
3. Serrano MC, Pagani R, Ameer GA, Vallet-Regí M, Portolés MT. Endothelial cells derived from circulating progenitors as an effective source to functional endothelialization of $\mathrm{NaOH}$-treated poly(epsilon-caprolactone) films. J Biomed Mater Res A 2008; 87: 964-971.

4. Diao Y, Guthrie S, Xia S-L, Ouyang X, Zhang L, Xue J, Lee P, Grant M, Scott E, Segal MS. Long-term engraftment of bone marrow-derived cells in the intimal hyperplasia lesion of autologous vein grafts. Am J Pathol 2008; 172: 839-848.

5. Rotmans J, Heyligers JMM, Verhagen HJM, Velema E, Nagtegaal MM, de Kleijn DPV, de Groot FG, Stroes ESG, Pasterkamp G. In vivo cell seeding with anti-CD34 antibodies successfully accelerates endothelialization but stimulates intimal hyperplasia in porcine arteriovenous expanded polytetrafluoroethylene grafts. Circulation 2005; 112: 12-18.

6. Kaul U, Bhatia V, Ghose T, Gupta R, Kachru R, Singh G. Angiographic followup of genous bioengineered stent in acute myocardial infarction (GENAMI) - a pilot study. Indian Heart J 2008; 60: 532-535.

7. Miglionico M, Patti G, D’Ambrosio A, Di Sciascio G. Percutaneous coronary intervention utilizing a new endothelial progenitor cells antibody-coated stent: a prospective single-center registry in high-risk patients. Catheter Cardiovasc Interv 2008; 71: 600-604.

8. Co M, Tay E, Lee CH, Poh KK, Low A, Lim J, Lim IH, Lim YT, Tan HC. Use of endothelial progenitor cell capture stent (Genous Bio-Engineered R Stent) during primary percutaneous coronary intervention in acute myocardial infarction: intermediate- to long-term clinical follow-up. Am Heart J 2008; 155: 128-132.

9. Aicher A, Brenner W, Zuhayra M, Badorff C, Massoudi S, Assmus B, Eckey T, Henze E, Zeiher AM, Dimmeler S. Assessment of the tissue distribution of transplanted human endothelial progenitor cells by radioactive labeling. Circulation 2003; 107: 2134-2139.

10. Roy I, Gupta MN. Freeze-drying of proteins: some emerging concerns. Biotechnol Appl Biochem 2004; 39: 165-177.

11. Lewandowska K, Kaplan D, Husel W. CD34 expression on platelets. Platelets 2003; 14: 83-87.

12. Strijbos MH, Kraan J, den Bakker MA, Lambrecht BN, Sleijfer S, Gratama JW. Cells meeting our immunophenotypic criteria of endothelial cells are large platelets. Cytometry B Clin Cytom 2007; 72: 86-93.

13. Yin M, Yuan Y, Liu C, Wang J. Combinatorial coating of adhesive polypeptide and anti-CD34 antibody for improved endothelial cell adhesion and proliferation. J Mater Sci Mater Med 2009; 20: 1513-1523.

14. Stellos K, Gnerlich S, Kraemer B, Lindemann S, Gawaz M. Platelet interaction with progenitor cells: vascular regeneration or inquiry? Pharmacol Rep 2008; 60: 101-108.

15. de Mel A, Jell G, Stevens MM, Seifalian AM. Biofunctionalization of biomaterials for accelerated in situ endothelialization: a review. Biomacromolecules 2008; 9: 2969-2979.

16. Markway BD, McCarty OJT, Marzec UM, Courtman DW, Hanson SR, Hinds MT. Capture of flowing endothelial cells using surface-immobilized anti-kinase insert domain receptor antibody. Tissue Eng Part C Methods 2008; 14: 97-105.

17. Avci-Adali M, Paul A, Ziemer G, Wendel HP. New strategies for in vivo tissue engineering by mimicry of homing factors for self-endothelialisation of blood contacting materials. Biomaterials 2008; 29: 3936-3945.

18. Ziegelhoeffer T, Fernandez B, Kostin S, Heil M, Voswinckel R, Helisch A, Schaper W. Bone marrow-derived cells do not incorporate into the adult growing vasculature. Circ Res 2004; 94: 230-238.

19. Perry TE, Song M, Despres DJ, Kim SM, San H, Yu Z-X, Raghavachari N, Schnermann J, Cannon 3rd RO, Orlic D. Bone marrow-derived cells do not repair endothelium in a mouse model of chronic endothelial cell dysfunction. Cardiovasc Res 2009; 84: 317-325.

20. Goodman SL. Sheep, pig, and human platelet-material interactions with model cardiovascular biomaterials. J Biomed Mater Res 1999; 45: 240-250. 